\title{
PERILAKU AGRESIF ANAK DISEBABKAN ORANG TUA MERANTAU
}

\author{
Dita Ratna Sari ${ }^{1}$, Mizaniya ${ }^{2}$, Ahmad Noviansah ${ }^{3}$ \\ 1,2,3 Mahasiswa Program Studi PGMI, UIN Sunan Kalijaga Yogyakarta, Indonesia \\ e-mail : ${ }^{\text {ditaratnasari10@gmail.com, }{ }^{2} 19204080018 @ \text { student.uin-suka.ac.id, }}$ \\ 319204080012@student.uin-suka.ac.id
}

\begin{abstract}
This paper focuses on the aggressive behavior of children caused by parents in formal education, namely SDN Delegen 3. The background of this study is that the child who behaved aggressively was abandoned by his parents so that this aggressively behaved child lacked the compassion, attention, upbringing, and guidance of his parents, where the whole parenting \& upbringing was handed over to his grandmother resulting in aggressive behavior in the surrounding environment. This research aims to find out the aggressive behavior of children in formal education and to know the consequences resulting from aggressive behavior towards one's own person. This research method uses case study research with a qualitative approach. Data collection techniques are done in three ways, namely interviews, observations, and documentation. Then came the results of the study, namely the aggressive behavior of the child left behind by the master wandering in formal education there are four types of forms: physically aggressive, verbally aggressive, anger, and hostility. First, forms of aggressive behavior such as pounding, highlighting, gripping, crashing, obstructing are physically aggressive. Second, da forms of aggressive behavior uttering such as mocking (screeching), saying rude is showing a verbally aggressive category. Third, the DA forms aggressive behavior such as threatening, as well as tinging pens showing a category of anger where when not achieved the desired goal. Fourth, da form of aggressive behavior does not show feelings of sentiment or suspicion towards others so in this study for the category of hostility is not visible.
\end{abstract}

Keywords: Aggressive Behavior, Parents, Wandering.

\begin{abstract}
Abstrak
Didalam tulisan ini memfokuskan kepada tingkah laku agresif anak yang disebabkan orang tua meratau di pendidikan formal yaitu SDN Delegen 3. Latar belakang penelitian ini yaitu anak yang bertingkah laku agresif ditinggalkan oleh kedua orang tuanya merantau sehingga anak yang berperilaku agresif ini kurang kasih sayang, perhatian, didikan, dan bimbingan dari orang tuanya, dimana seluruh pengasuhan \& didikan diserahkan terhadap neneknya sehingga mengakibatkan bertingkah laku agresif di lingkungan sekitarnya. Penelitian ini bertujuan untuk mengetahui tingkah laku agresif anak pada pendidikan formal dan mengetahui akibat yang yang ditimbulkan dari tingkah laku agresif terhadap pribadi sendiri. Metode penelitian ini menggunaka penelitian study kasus dengan pendekatan kualitatif. Teknik pengumpulan data dilakukan dengan tiga cara yaitu wawancara, observasi, serta dokumentasi. Lalu timbullah hasil penelitian yaitu perilaku agresif anak yang ditinggal orang tuannya merantau pada pendidikan formal terdapat empat jenis bentuk: agresif secara fisik, agresif secara verbal, kemarahan, serta permusuhan. Pertama, bentuk tingkah laku agresif seperti mementung (menggebuk), menjorokkan (memerosokkan), mencengkam, menerjang, menghalangi ialah memperlihatkan kategori agresif secara fisik. Kedua, DA bentuk tingkah laku agresif mengucapkan seperti mengejek (meledek), berkata kasar ialah memperlihatkan kategori agresif secara verbal. Ketiga, DA bentuk tingkah laku agresif seperti mengancam, serta melantingkan pena memperlihatkan kategori kemarahan dimana apabila tidak tercapai tujuan yang diinginkan. Keempat, DA bentuk tingkah laku agresif tidak memperlihatkna perasaan sentimen ataupun curiga terhadap orang lain sehingga pada penelitian ini untuk kategori permusuhan tidak tampak.
\end{abstract}

Kata Kunci: Perilaku Agresif, Orang Tua, Merantau. 
Perubahan zaman dan perubahan social pada era sekarang ini membawa kita semua kepada perubahan gaya hidup. Perubahan-perubahan tersebut juga membawa dampak bertambahnya kebutuhan hidup sehari-hari dan berdampak juga pada cara orang tua dalam mengasuh anak. Jika zaman dahulu hanya seorang ayah yang merantau mencari nafkah sedangkan ibu menjadi ibu rumah tangga. Namun sekarang seorang ibu juga ikut merantau dan merantau, sehingga ayah dan ibu (orang tua) sama-sama merantau tujuannya untuk memenuhi kebutuhan. Berdasarkan data dari Badan Pusat Statistik Tingkat Partisipasi Angkatan Kerja (TPAK) perempuan di negara Indonesia mengalami peningkatan dalam keluarga yang orang tua merantau pada bulan Februari 2017 sebesar 55,04 persen dimana angka persentase tersebut pada bulan Februari 2018 mengalami peningkatan sebesar 0,40 persen sehingga menjadi 55,44\%. ${ }^{1}$ Berdasarkan laporan dari McKinsey Global Institute mencatat sebesar $45 \%$ pekerja kerah putih diisi oleh kaum hawa di Indonesia. Dimana angka tersebut hampir mendekati setengah jumlah kerah putih yang ada di Indonesia. ${ }^{2}$

Dilihat dari peningkatan manusia yang merantau diluar kota maupun luar negeri akan berdampak pada pertumbuhan perekonomian Indonesia yang kaan membawa dampak baik terhadap kesejahteraan masyarakat Indonesia. Tetapi pada kenyataannya dampak yang terjadi kepada anak ketika kedua orang tua sama-sama merantau yaitu menyebabkan anak menjadi kurang perhatian dan mengakibatkan bergesernya peran kedua orang tua yang bertanggung jawab dalam mengasuh dan merawat anak, pada akhirnya pengasuh nenek atau kakek dan anggota keluarga lainnya yang menjadi andalan dalam merawat dan menggantikan peran kedua orang tua dalam mengasuh seorang anak. Hal ini terjadi biasanya karena orang tua yang merantau akan meninggalkan anaknya di daerah asal. Menurut Yuli Singgih menyatakan bahwa anak yang ditinggal oleh orang tua merantau mereka mempunyai kebiasaan menyusun dan menetapkan dengan diri sendiri keputusan yang dianggap baik. Orang tua yang merantau memiliki kesibukan dalam kegiatannya sehingga jarang pulang ke rumah. Orang tua yang merantau akan pulang ke rumah apabila ada izin dari bos ataupun majikan dari tempat bekerja waktu pulang pun kemungkinan waktu lebaran sehingga mengasuh ataupun mendidik anak tidak ada waktu dengan sebaikbaiknya. Sehingga yang mengasuh ataupun mendidik anak yang ditinggal dirumah dipercayakan kepada pengasuh ataupun anggota keluarga lainnya. ${ }^{3}$

Berdasarkan hasil wawancara peneliti dengan salah satu narasumber yaitu nenek dari anak yang memiliki tingkah laku agresif dengan inisial nenek $\mathrm{H}$ ini merupakan pengasuh dari rumah kepada DA. Nenek H mengungkapkan bahwa orang tua dari DA tidak pernah bertanya kesulitan yang dialami dari

\footnotetext{
${ }^{1}$ Berita Resmi Statistika, 2018, Keadaan Ketenagakerjaan Indonesia Februari 2018, Diunduh dari laman web http://www.turc.or.id/wp-content/uploads/2018/06/BPS_Berita-Resmi-Statistik_Keadaan-Ketenagakerjaan-IndonesiaFebruari-2018.pdf Pada tanggal 04 Desember 2018 pukul 14.45 WIB.

${ }^{2} \mathrm{CNN}$ Indonesia, 2018, Diunduh dari laman web https://www.cnnindonesia.com/gaya-hidup/20181222032125284-355682/pilihan-ibu-berkarier-atau-mengurus-anak-tak-pernah-salah Pada tanggal 02 Februari 2019 Pukul 10.10 WIB.

${ }^{3}$ Yulia Singgih D Gunarsa, Psikologi Perkembangan Anak dan Remaja, (Jakarta: PT BPK Gunung Mulia, 2008), hlm. 83 .
} 
Dita Ratna Sari, Mizaniya, Ahmad Noviansyah : Perilaku Agresif Anak Disebabkan Orang Tua Merantau

DA di rumah, sekolah, lingkungan bersosial, bermain, dan sebagainya. Selain itu orang tua pun tidak menanyakan apabila anak menjalankan tingkah laku yang menyimpang. Hal ini nenek $\mathrm{H}$ lah yang harus bertanggung jawab terhadap kegiatan ataupun didikan terhadap DA dikarenakan orang tua telah menyerahkan seluruh pengasuhan DA kepada nenek H. Sehingga orang tua DA pun telah percaya kepada nenek $\mathrm{H}$ apabila ada keputusan kegiatan yang dilakukan dari cucunya tersebut. Nenek $\mathrm{H}$ mempunyai keterbatasan dalam mengasuh serta mendidik dikarenakan usia sudah lansia dan mestinya tidak boleh terjadi hal tersebut. Menurut peneliti berdasarkan hasil penelitian ini ialah kedua orang tua dari DA yang merantau hanya memberikan nafkah berupa uang akan tetapi tidak memberikan secara utuh kasih sayang, perhatian, didikan kepada DA. Ini merupakan fakta yang ada dilapangan dari penelitian ini terlihat bahwa kedua orang tua dari DA yang merantau sehingga kurangnya komunikasi serta kerja sama dalam mendidik dan mengasuh DA dengan nenek $\mathrm{H}$.

Anak mempunyai tingkah laku atau sikap (sifat) contohnya seperti memiliki tingkah laku kepada teman yang kurang baik, memiliki sifat pembangkang, sering meyakiti terhadap teman, memalak duit terhadap teman dengan paksa, menggerecoki (mengusili) teman di kelas saat masih dalam proses pembelajaran, emosi tidak mudah terkontrol, menggebuk (mementung) teman, dan sebagainya ini merupakan kurangnnya kasih sayang ataupun perhatian serta bimbingan penuh dari kedua orang tuanya ialah salah satu faktor yang menyebabkan tingkah laku agresif pada anak yang disebabkan orang tua yang merantau. Sejalan dengan menurut Anantasari dalam bukunya mengemukakan bahwa kurang kasih sayang ataupun perhatian dari kebutuhan anak menyebabkan anak akan melampiaskan emosi dalam kemarahan pada orang lain disekitarnya bahkan kepada kedua orang tua sehingga anak-anak akan mempunyai sifat membangkang menyebabkan hubungan dalam keluarga terciptanya permusuhan serta tindakan agresi terhadap anggota lainnya. ${ }^{4}$

Berdasarkan hasil wawancara peneliti dengan salah satu narasumber yaitu ibu FN ialah wali kelas IV di SDN Delegan 3 beliau mengungkapkan bahwa ada dua orang peserta didik yang bertingkah laku agresif serta susah untuk dikendalikan. Akan tetapi, DA ialah hanya satu-satunya peserta didik yang bertingkah laku agresif yang ditinggalkan oleh orang tuanya merantau di SDN Delegan 3. Ibu FN menyatakan bahwa DA juga menderita kesulitan belajar membaca atau yang sering disebut dengan diseleksia dan kesulitan belajar berhitung atau yang sering disebut dengan diskalkuli. Selain itu DA sering kali tidak mengerjakan pekerjaan rumah (PR) yang telah diberikan serta kalau mengerjakan tugas ataupun soal di dalam kelas jarang selesai tepat pada waktunya. Ibu FN mengemukakan bahwa DA ialah peserta didik yang paling tua umurnya \& paling besar badannya di dalam kelas sehingga ia dapat menguasai teman sejawatnya di dalam kelas serta tingkah laku agresifnya tidak dapat dikendalikan ketika ia naik ke kelas III. Ibu FN menyebutkan bahwa tingkah laku agresif dari DA dikarenakan salah satunya kurang perhatian dari kedua orang tuanya yang merantau sehingga dalam kehidupan sehari-hari DA tinggal bersama neneknya.

\footnotetext{
${ }^{4}$ Anantasari, Menyikapi Perilaku Agresif Anak, (Yogyakarta: Kanisius, 2006), hlm. 108. Al-Madrasah: Jurnal Ilmiah Pendidikan Madrasah Ibtidaiyah Vol. 5, No. 1, Juli-Desember 2020
} 
Tingkah laku agresif pada anak yang disebabkan orang tua merantau dan akibat dari tingkah laku agresif pada anak tersebut merupakan masalah urgent yang utama harus dikaji secara mendalam. Kehidupan psikis pada pendidikan formal anak di jenjang sekolah dasar merupakan fase laten dimana anak senang belajar, tenang, senang main dan dalam dunia luar sudah terarah hidupnya. Kecakapan dari segi intelektual pada anak mengalami perkembangan yang sangat pesat selain kecakapan social lainnya. ${ }^{5}$ Orang tua ialah pendidikan pertama yang didapatkan oleh anak. Kebutuhan pangan, sandang, fisik, mental, maupun psikis dari anak harus terpenuhi secara seimbang dari kedua orang tua. Orang tua yang sibuk merantau harus dapat memberikan kasih sayang dan bimbingan terhadap buah hari yang ditinggal dirumah. Berdasarkan teori tingkah laku agresif anak ditimbulkan dampak dari ditinggalkan oleh kesibukan kedua orang tua merantau ialah membuat anak kurang perhatian dan kasih sayang dari mereka sehingga akan membuat anak untuk melampiaskan kemarahannya terhadap orang lain serta dapat memicu tindakan tingkah laku agresif di sekitar lingkungannya. Sehingga tingkah laku agresif anak dapat merasakan akibat negative atau buruk terhadap pribadi sendiri contohnya sulit bergaul, anak dijauhi oleh teman-teman bermain disekitarnya sehingga membuat kesenjangan social, dan sebagainya.

Berdasarkan pernyataan latar belakang uraian di atas maka peneliti bermaksud untuk mengadakan penelitian tentang perilaku agresif anak sekolah dasar sehingga peneliti tertarik untuk mengangkat penelitian dengan judul "Perilaku Agresif Anak Disebabkan Orang Tua Merantau" agar dapat diungkap jawaban-jawaban dari persoalan ini.

\section{METODE PENELITIAN}

Peneliti memakai metode field research (penelitian lapangan) pada penelitian ini. Metode Field research dilakukan dilokasi lapangan secara langsung. Mengenai perilaku agresif peserta didik di pendidikan formal sekolah dasar dikarenakan ditinggalkan oleh orang tua yang merantau dan akibat yang timbul dari tingkah laku agresif terhadap pribadi sendiri serta kawan sejawat dilingkungan sekitarnya ini merupakan alasan peneliti memilih metode field research (penelitian lapangan) menginginkan dimana untuk menyelidiki serta menerangkan data penelitian tersebut. Penelitian memakai pendekatan kualitatif. Penelitian naturalistic atau yang dikenal juga dengan penelitian kualitatif ialah dikarenakan penelitian ini dilaksanakan saat keadaan alami (biasa) melalui mengamati (mencermati) lokasi ditempat penelitian serta dari data kualitatif, tidak memakai jenis matematik statistic serta deskriptif analitis ialah sifat analisisnya. ${ }^{6}$ Penelitian ini ialah jenis penelitian studi kasus. Penelitian yang mendalam mengenai individu, kelompok, organisasi, kegiatan, dan lain-lain selama jangka tertentu ialah studi kasus. Studi kasus memiliki tujuan mendapatkan deskripsi secara mendalam serta utuh dari sebuah entitas. Penelitian kualitatif seperti mana untuk perolehan data studi kasus dari

\footnotetext{
${ }^{5}$ Anak Agung Ngurah Adhiputra, Bimbingan dan Konseling Aplikasi di Sekolah Dasar dan Taman Kanak-kanak, (Yogyakarta: Graha Ilmu, 2013), hlm. 25.

${ }^{6}$ Muh. Fitrah dan Luthfiyah, Metodologi Penelitian (Penelitian Kualitatif, Tindakan Kelas Dan Studi Kasus, (Jawa Barat: CV Jejak, 2017), hlm. 44.

Al-Madrasah: Jurnal Ilmiah Pendidikan Madrasah Ibtidaiyah
}

Vol. 5, No. 1, Juli-Desember 2020 
wawancara, observasi, arsip, dan sebagainya. ${ }^{7}$ Penelitian ini ada tiga tahapan yang dilakukan oleh peneliti yakni tahap persiapan, pelaksanaan \& pelaporan, serta penyelesaian ialah desain penelitian.

Nenek dari DA, guru \& peserta didik kelas IV di SDN Delegan 3 merupakan subjek pada penelitian ini. Penelitian ini menggunakan dua jenis sumber data yaitu sumber data primer dan sekunder. Nenek dari DA, guru \& peserta didik kelas IV di SDN Delegan 3 merupakan sumber data primer dalam penelitian. buku, jurnal, badan statistic, dokumen, dan lain-lain untuk menunjang validasi data pada penelitian ini merupakan sumber data sekunder.

Teknik pengumpulan data dilakukan dengan tiga cara yaitu wawancara, observasi, serta dokumentasi di dalam penelitian ini. Observasi dilakukan oleh peneliti dengan cara melakukan pengamatan mengenai tingkah laku agresif dari DA di pendidikan formal yakni SDN Delegan 3 dikarenakan ditinggalkan oleh orang tua yang merantau dan akibat yang timbul dari tingkah laku agresif terhadap pribadi sendiri serta kawan sejawat dilingkungan sekitarnya. Wawancara terstruktur yaitu pertanyaan yang tertulis secara sistematis dengan pola tertentu dan format yang baku. ${ }^{8}$ Jenis wawancara yaitu wawancara terstruktur dilakukan dengan menggunakan instrument yang telah dibuat oleh peneliti di dalam penelitian ini. Foto-foto dari tingkah laku agresif DA di pendidikan formal SDN Delegan 3, bukti wawancara dari nenek DA, serta transkip wawancara dari nenek DA, guru, \& peserta didik kelas IV di SDN Delegan 3.

Peneliti mengenakan triangulasi terhadap penelitian yang dilakukan untuk terhadap teknik mengadakan pengecekan keabsahan data. Pengecekan data dari sumber dengan berbagai cara $\&$ waktu ialah arti dari triangulasi dalam pengujian kredibilitas. Triangulasi teknik merupakan pengujian kredibilitas dalam penelitian ini. Mengecek data kepada sumber yang sama akan tetapi dengan teknik yang berbeda ialah untuk menguji kredibilitas data pada triangulasi teknik dalam penelitian. ${ }^{9}$ Teknik pengumpulan data yang dilakukan dengan tiga cara yaitu observasi, wawancara, serta dokumentasi di dalam penelitian ini. Nenek DA, guru, \& peserta didik kelas IV di SDN Delegan 3.

Reduksi data, penyajian data serta penarikkan kesimpulan pada penelitian memakai model dari Metthew B. Miles \& Huberman ialah teknik analisis data. Berikut dari langkah-langkah dalam analisis data yakni Pertama, membikin ringkasan, mengkode, menelusur tema, dan lain-lain ialah kegiatan yang dilaksanakan sejak pengumpulan data saat reduksi data. ${ }^{10} \mathrm{Kedua}$, bersifat naratif pada penelitian ini untuk penyajian datanya. Original dari tutur kata pewawancara \& narasumber saat melakukan wawancara ialah penyajian data yang dinarasikan dalam penelitian ini. Ketiga, verifikasi/penegasan

\footnotetext{
${ }^{7}$ Connie Chairunnissa, Metode Penelitian Ilmiah Aplikasi dalam Pendidikan dan Sosial, (Jakarta: Mitra Wacana Media, 2017), hlm. 64. 376.

${ }^{8}$ Muri Yusuf, Metode Penelitian Kuantitatif, Kualitatif \& Penelitian Gabungan, (Jakarta: Kencana, 2017), hlm.

${ }^{9}$ Sugiyono, Metode Penelitian Kuantitatif, Kualitatif, dan R\&D, (Bandung: Alfabeta, 2016), hlm. 274.

${ }^{10}$ Andi Prastowo, Metode Penelitian Kualitatif dalam Perspektif Rancangan Penelitian, (Yogyakarta: Ar-Ruzz Media, 2011), hlm. 242.
}

Al-Madrasah: Jurnal Ilmiah Pendidikan Madrasah Ibtidaiyah

Vol. 5, No. 1, Juli-Desember 2020 
kesimpulan merupakan temuan baru yang sebelumnya belum pernah ditemukan. Sehingga kesimpulan dalam penelitian ini bisa menjawab rumusan masalah yang telah ditetapkan sebelumnya tetapi mungkin juga tidak karena rumusan masalah dalam penelitian kualitatif masih bersifat remang-remang dan akan berkembang setelah peneliti berada di lapangan. ${ }^{11}$

\section{KAJIAN TEORI}

\section{a. Perilaku Agresif}

Menurut Myres dalam bukunya Hidayat mengemukakan bahwa agresi ialah perilaku verbal ataupun fisik yang disengaja ataupun tidak disengaja akan tetapi memiliki maksud untuk menyakiti, menghancurkan, merugikan orang lain, ataupun melukai suatu objek yang akan menjadi sasaran agresinya. ${ }^{12}$ Menurut Moore \& Fine dalam bukunya Suprihatin menyatakan bahwa agresi ialah perilaku kekerasan secara verbal ataupun fisik terhadap objek maupun individu. Penggunaan kata-kata kasar seperti bodoh, tidak pintar, dan sebagainya ialah salah satu contoh dari agresif verbal. Sedangkan kekerasan yang dilakukan secara fisik seperti menampar, menendang, memukul, dan sebagainya ialah salah satu contoh dari agresif fisik. Agresi kerapkali dipakai oleh manusia untuk menyampaikan perasaan dan menyelesaikan masalah. ${ }^{13}$ Dari definisi para ahli disimpulkan bahwa perilaku agresif ialah perilaku yang mencederai dengan tujuan secara sengaja untuk menyakiti hati dan fisik seseorang yang tidak dapat diterima sikapnya.

Menurut Bush \& Perry dalam bukunya Hidayat menyebutkan bahwa agresivitas terbagi menjadi empat yakni agresi fisik, agresi verbal, kemarahan serta permusuhan. Setiap bentuk agresi akan mewakili ranah yang berbeda-beda. Komponen motoric dalam agresivitas mewakili dari agresi fisik dan verbal. Sedangkan komponen afektif dan kognitif mewakili dari kemarahan dan permusuhan. ${ }^{14}$ Pertama, agresi fisik bentuk tingkah laku agresif ini ialah melakukan dengan cara mencederai secara fisik tujuannya untuk melukai atau membahayakan seseorang. Jenis dari agresi fisik ini mudah untuk dilihat secara kasatmata dilapangan dikarenakan ada bukti fisiknya contohnya menikam, memukul, dan sebagainya sehingga membuat korban akan terluka. Kedua, agresi verbal bentuk tingkah laku agresif ini ialah dengan cara menyebutkan dengan kata-kata ataupun kalimat yang kasar atau maknanya kurang baik. Contohnya dari agresi verbal yaitu sindiran, fitnah, umpatan, sarkasme, hinaan, ucapan kasar atau kata-kata kotor. Ketiga, kemarahan bentuk tingkah laku agresif secara tidak langsung ini ialah perasaan benci terhadap orang lain ataupun suatu hal kepada seseorang dikarenakan tidak mencapai tujuan yang ia ingingkan. Contohnya dari kemarahan yaitu gagal, merasa kecewa, dikhianati, dan sebagainya bisa melebar

\footnotetext{
${ }^{11}$ Sugiyono, Metode Penelitian Kuantitatif, Kualitatif, dan R\&D, (Bandung: Alfabeta, 2016), hlm. 252-253.

${ }^{12}$ Komaruddin Hidayat dan Khoiruddin Bashori, Psikologi Sosial: Aku Kami dan Kita, (Jakarta: Erlangga, 2016), hlm. 131.

${ }^{13}$ Titin Suprihatin, Agresivitas Anak (Suatu Studi Kasus), Jurnal Proyeksi Vol. 6 No. 1 Tahun 2011, 53-61, hlm. 53-54.

${ }^{14}$ Komaruddin Hidayat dan Khoiruddin Bashori, Psikologi Sosial: Aku Kami dan Kita, (Jakarta: Erlangga, 2016), hlm. 133
} 
terhadap pihak lain yang tidak terkait secara tidak langsung serta yang ditujukan terhadap objek yang yang sebenarnya menjadi penyebab. Keempat, permusuhan bentuk tingkah laku agresif ini ialah komponen kognitif yang terdiri dari melawan ketidakadilan serta keinginan untuk menyakiti. Agresi tidak terlihat tergolong bentuk agresi ini ialah permusuhan terdiri dari kebencian ataupun kecurigaan.

Adapun ciri-ciri dari anak agresif terhadap apek kognitif, afektif, dan psikomotor. ${ }^{15}$ Pertama, anak agresif pada aspek kognitif yaitu sulit menalar, menangkap, berfikir apa yang diterima berdasarkan pengamatan yang dilakukan oleh indra pengelihatannya, sulit berkonsentrasi, serta kurang baik dalam menyampaikan ide. Kedua, anak agresif pada aspek afektif memiliki sikap yaitu cuek, membangkang, mau menang sendiri. Ketiga, anak agresif pada aspek psikomotor yaitu gerakan kurang terkoodinir dan selalu bergerak.

Ada beberapa faktor yang mempengaruhi anak untuk berperilaku agresif yaitu faktor biologis, pola asuh dalam keluarga, dan faktor social. Meresahkan diri sendiri, orang tua, teman bermain ataupun sekolah, dan guru ialah dampak dari perilaku agresif yang merugikan pada anak. Contohnya menjadi model perilaku yang kurang baik, menjadi perilaku fondasi, dan jauhi oleh teman ialah dampak dari tingkah laku agresif pada diri sendiri. ${ }^{16}$ Tingkah laku anak agresif agar tidak semakin buruk yang harus diperhatikan oleh orang tua yaitu membangun \& mengkontrol media komunikasi yang dipakai oleh anak, orang tua harus mengendalikan diri sendiri untuk tidak bersikap mencela anak, mengajarkan empati kepada orang lain, serta membuat ruang kedekatan dan kehangatan kepada anak, dan lain-lain. ${ }^{17}$

\section{b. Orang Tua Merantau}

Menurut bahasa kata orang tua berasal dari orang dan tua. Arti orang ialah manusia sedangkan arti tua ialah lanjut usia. Disimpulkan makna arti orang tua ialah orang yang lanjut usia atau sepuh. ${ }^{18}$ Menurut peneliti disimpulkan bahwa orang tua ialah laki-laki dan perempuan yang telah mengikat janji suci didalam suatu pernikahan yang telah siap menanggung kebutuhan fisik, mental, psikis, serta pendidikan dari buah hati mereka yang ada di dalam keluarga inti nantinya.

Melayu, Minangkabau, serta Indonesia untuk istilah akar kata "merantau" artinya sama serta penggunakan dalam bahasa. Menurut Winstedt, Iskandar, dan Purwadarminta dalam bukunya Djanaid menyatakan arti rantau yaitu dataran rendah sehingga terletak dari bagian dengan daerah pesisir. Pergi ke rantau arti dari makna merantau yang di awali dari kata kerja "me-". ${ }^{19}$ Menurut

\footnotetext{
${ }^{15}$ Syamaun, Nurmasyithah, Dampak Pola Asuh Orang Tua dan Guru Terhadap Kecenderungan Perilaku Agresif Siswa, (Yogyakarta: Ar-Ruzz Media, 2012), hlm. 64.

${ }^{16}$ Anantasari, Menyikapi Perilaku Agresif Anak, (Yogyakarta: Kanisius, 2006), hlm. 95-96.

${ }^{17}$ Anantasari, Menyikapi Perilaku Agresif Anak, (Yogyakarta: Kanisius, 2006), hlm. 109. hlm. 192

${ }^{18}$ Tim Dosen PAI, Bunga Rampai Penelitian dalam Pendidikan Islam, (Yogyakarta: CV Budi Utama, 2016),

${ }^{19}$ Djanalis Djanaid dan Maharjo, Manajemen dan Leadership dalam Budaya Minangkabau, (Malang: Universitas Brawijaya Press, 2011), hlm. 33.
} 
peneliti disimpulkan bahwa merantau ialah pergi keluar dari kampung halaman untuk mencari penghasilan dalam waktu tertentu dan akan kembali lagi ke kampung halaman apabila sudah mencukupin kehidupan.

Disimpulkan makna arti orang tua merantau ialah sepasang laki-laki dan perempuan yang sering dipanggil dengan sebutan ibu dan bapak dari buah hatinya yang telah terikat perikahan dan mereka pergi dari kampung halaman untuk mencari penghasilan serta mencukupi kebutuhan keluarga inti dalam waktu tertentu dan akan kembali lagi ke kampung halaman.

Metode didikan dari orang tua kepada anak ialah makna dari pola asuh. Menurut Wahyuning dalam bukunya menyatakan bahwa bagian paling penting hal yang mendasar untuk merencakan agar buah hati mempunyai perilaku yang baik dalam kehidupan bermasyarakat ialah makna dari pengasuhan anak. ${ }^{20}$ Waktu berada dirumah sangat jarang bagi orang tua yang merantau. Interaksi orang tua kepada anak sangat terbatas ialah dampak dari orang tua merantau. Pendidikan karakter bagi anak ditentukan dari pola asuh orang tua yang baik \& tepat. Kesalahan dalam pembentukan karakter pada anak akan mengakibatkan karakter kurang baik ialah dampak kesalahan dalam pola pengasuhan orang tua sehingga akan membangun generasi masa depan bangsa yang kacau. ${ }^{21}$

Menurut Hurlock, Harley, \& Heyes dalam bukunya Fathi menyampaikan ada tiga jenis dalam pola asuh orang tua terhadap anak ialah Pertama, keluarga yang menganut pola asuh ini biasanya anak-anaknya tidak memiliki kebebasan dalam berpendapat dan melakukan kegiatan apapun karena orang tua mereka yang dominan maka dinamakan pola asuh otoriter. Pola asuh otoriter memiliki ciri khas yaitu biasanya dikontrol secara ketat pada perilaku buah hatinya, orang tua lebih dominan dalam lingkup keluarga inti, ucapan atau tindakan dari orang tua dalam pola asuh otoriter ialah mutlak atau tidak bisa diganggu gugat oleh siapapun, apabila buah hati mereka membangkang terhadap yang diberikan oleh orang tuanya maka anak tersebut akan mendapatkan hukuman serta argumentasi yang di ucapkan oleh buat hati tidak akan di dengarkan oleh orang tua yang menganut pola asuh secara otoriter serta tidak adanya pengakuan eksistensi kepada buah hatinya di dalam keluarga inti. Kedua, keluarga yang menganut pola asuh ini biasanya menjunjung tinggi kerjasama, terbuka dalam beragumentasi dan lain-lain maka dinamakan pola asuh demoktratis. Pola asuh demokratis memiliki ciri khas yaitu adanya keterbukaan dalam menyampaikan argumentasi antara orang tua terhadap buah hatinya, adanya kerjasama yang baik antara orang tua dengan anaknya, adanya pengakuan dari orang tua kepada anaknya dalam eksistensi di dalam keluarga inti tentunya buah hati dari mereka adanya pengasawan dari orang tua. Ketiga, keluarga yang menganut pola asuh ini biasanya membebaskan anak dalam hal apapun maka dinamakan pola asuh permisif. Pola asuh permisif memiliki ciri khas yaitu orang tua yang

\footnotetext{
${ }^{20}$ Wiwit Wahyuning, Jash dan Metta Rachmadiana, Mengkomunikasikan Moral Kepada Anak, (Jakarta: PT Elex Media Komputido, 2003), hlm. 126.

${ }^{21}$ Bunda Fathi, Mendidik Anak dengan Al-Qur'an Sejak Janin, (Jakarta: Grasindo, 2011), hlm. 59. Al-Madrasah: Jurnal Ilmiah Pendidikan Madrasah Ibtidaiyah Vol. 5, No. 1, Juli-Desember 2020
} 
menganut pola asuh permisif biasanya tidak adanya control \& bimbingan kepada buah hatinya, orang tua biasanya bersikap longgar terhadap tingkah laku ataupun kegiatan yang buah hatinya lakukan, buah hati mereka sendirilah yang bertanggung jawab terhadap tingkah laku ataupun kegiatan yang dilakukan sepenuhnya, adanya kurang perhatian dari orang tuanya, dan lain-lain. ${ }^{22}$

\section{HASIL DAN PEMBAHASAN}

\section{a. Perilaku Anak Di Sekolah Yang Disebabkan Oleh Orang Tua Yang Merantau}

Dari rentangan yang ringan hingga berat ada banyak ragam terhadap perilaku agresif. Diklasifikasikan ada empat bentuk perilaku agresif anak yakni agresif fisik, agresif verbal, kemarahan dan permusuhan serta memiliki ciri-ciri yang dapat dilihat dari berbagai aspek yaitu aspek kognitif, afektif, dan psikomotor. Berdasarkan hasil penelitian yang telah dilakukan oleh peneliti bahwa perilaku agresif anak di SD Negeri Delegan 3 di sebabkan oleh orang tua yang merantau, sebagai berikut:

1) Agresif Fisik

Agresif fisik dilakukan dengan cara menyerang secara fisik untuk melukai seseorang. Berdasarkan hasil pengamatan yang dilakukan oleh peneliti saat proses pembelajaran berlangsung pada 18 April 2019 untuk agresif fisik dilakukan oleh DA terhadap temannya bernama $\mathrm{F}$ yaitu DA melakukan pelemparan gunting terhadapnya akan tetapi $\mathrm{F}$ menghindar sehingga tidak mengenai anggota badan F dan tidak terluka. Lalu F merasa ketakutan terhadap perbuatan DA kepadanya sehingga membuat ia mengadukan perilaku DA kepada bu guru, selanjutnya bu guru langsung menyita gunting yang ada di DA tersebut. DA melakukan perilaku agresif terhadap F tanpa adanya alasan ataupun sebab, dimana perilaku agresif ini dilakukan DA secara tiba-tiba.

DA melakukan perilaku agresif lagi terhadap teman sekelasnya. Berdasarkan hasil pengamatan yang dilakukan oleh peneliti saat proses pembelajaran berlangsung pada 19 April 2019 untuk perilaku agresif fisik oleh DA terhadap temannya bernama E yaitu DA dari belakang secara tiba-tiba melakukan mendorong dan menendang E sampai kepentok ke papan tulis yang ada dikelas ketika E ingin istirahat di luar kelas. Sambil menggerutu E mengatakan kepada DA yaitu "koe ki ngopo to dim" artinya "kamu kenapa gitu dim" lalu sahut DA dengan tertawa. Lalu E kembali ke tempat duduk di dalam kelas sampai menunggu DA untuk pergi. Selain itu, saat pembelajaran perilaku agresif fisik oleh DA terhadap temannya bernama LK yaitu dipicu saling ejek antara keduanya sehingga DA melakukan memukul punggung LK lalu mendorongnya sehingga LK terjatuh tersungkur serta DA mencekik leher LK sampai kancing bajunya LK terlepas.

\footnotetext{
${ }^{22}$ Bunda Fathi, Mendidik Anak dengan Al-Qur'an Sejak Janin, (Jakarta: Grasindo, 2011), hlm. 59.
} 
Perilaku agresif lagi yang dilakukan oleh DA yaitu menyebarkan sampah kertas di depan kelas. Lalu DA diminta untuk membersihkan sampah kertas tersebut oleh guru yang melihat aksinya. Kemudian DA pun mengambil sapu di lemari kelas, ketika DA mau mengambil sapu saat itu ada temannya yang bernama W yang sama-sama mau ambil sapu juga. Setelah itu DA secara tiba-tiba mendorong $\mathrm{W}$ ke belakang pintu lemari dan dijepitkan olehnya. Lalu W pun menangis atas perbuatan yang dilakukan DA terhadapnya.

Berdasarkan hasil pengamatan yang dilakukan oleh peneliti pada 20 April 2019 DA pun melakukan perilaku agresif lagi terhadap teman sekelasnya bernama YR yaitu menjegal kaki ketika YR hendak bertanya kepada guru saat proses pembelajaran berlangsung, sehingga membuat YR terjatuh tersunggur di lantai kelas. Lalu YR pun segera cepat berdiri dan maju kedepan meja guru di dalam kelas akan tetapi DA selalu mengejar dan menendang YR. Secara tiba-tiba perilaku agresif fisik yang dilakukan oleh DA tanpa adanya sebab ataupun alasan. Selain itu, sebelumnya saat pembagian buku tugas dimeja bu guru di dalam kelas, buku tugasnya DA tidak ditemukan. Sehingga membuat DA marah lalu mengumpat serta secara tidak sengaja DA melihat ada teman sekelasnya bernama FM dimana ia sedang berdiri di depan pintu kelas. Setelah itu secara tiba-tiba dan tanpa adanya alasan DA menendang dan memukul kepalanya FM serta mendorongnya sampai keluar kelas.

Disimpulkan bahwa berdasarkan hasil penelitian observasi, wawancara, dan dokumentasi yang telah dilakukan oleh peneliti terhadap perilaku agresif fisik yang telah dilakukan oleh DA terhadap teman sekelasnya ialah melempar gunting, mendorong, menjegal, memukul, menendang, dan mencekik. Perbuatan atas perilaku agresif secara fisik oleh DA membuat temanteman kelasnya seringkali menangis ataupun ketakutan. DA melakukan perilaku agresif secara fisik terjadi terkadang dikarenakan hal yang sepele contohnya aksi saling ejek, marah kepada temannya, ataupun kejailan dari DA sendiri. Perilaku agresif fisik yang dilakukan oleh DA terkadang secara tiba-tiba dan tanpa adanya alas an yang jelas.

2) Agresif Verbal

Agresif verbal dapat berupa hinaan, sarkasme, umpatan, fitnah, sindiran, dan ucapan katakata kotor dan kasar. DA sangat sering melakukan agresif verbal terhadap teman-temannya di sekolah. DA sangat acuh apabila perkataan kurang baik yang terlontar dari mulutnya didengar oleh guru yang ada di sekolah. Berdasarkan hasil pengamatan yang dilakukan oleh peneliti pada 18 April 2019 saat pembelajaran materi prakarya di dalam kelas mengenai pembuatan poster. Saat itu DA melakukan menggunting bahan prakarya berupa kardus lalu dibuatnya untuk bermain bahan tersebut, padahal bahan prakarya tersebut digunakan berkelompok. Sehingga ada teman sekelompoknya bernama L meminta kardus tersebut kembali lalu mengambilnya, akan tetapi ditolak serta direbut kembali kardus tersebut oleh DA serta melontarkan kata-kata yang kasar serta hinaan kepada L dalam bahasa jawa yaitu "woo koe iki petok" yang artinya dalam bahasa 
Indonesia ialah dasar kamu bodoh sehingga membuat L tidak jadi mengambil bahan kardus serta langsung terdiam di tempat duduk di kelas tersebut. Kemudian, DA melakukan kejailan terhadap temannya yang lain.

DA melontarkan kata yang kotor dalam bahasa jawa yaitu modar yang artinya dalam bahasa Indonesia ialah mati. DA melontarkan kata yang kotor ketika ia berdiri dari meja kursi belajar di dalam kelas ketika hendak keluar akan tetapi kakinya tersandung dengan kursi tersebut. Kemudian dikarenakan kaki DA kesakitan sehingga ia memutuskan untuk duduk kembali. Setelah ia duduk tidak berapa lama kemudian DA bernyanyi akan tetapi DA merubah lirik lagu tersebut dengan bahasa yang kotor yaitu alat kelamin laki-laki sehingga membuat peneliti sangat kaget ketika mendengar nyanyian dari DA. DA pun melakukan kejailan kepada temannya. Kemudian DA pun mengajak teman sekelompoknya berjenis kelamin laki-laki untuk bernyanyi bersama. Dengan santai dan tertawa DA menyanyikan lagu dengan mengubah lirik dengan katakata kotor tersebut ketika guru mata pelajaran di dalam kelas yang sedang turun ke kantor dikarenakan mengambil buku paket.

Guru datang ke setiap meja belajar kelompok untuk mengecek sampai mana progress setiap kelompok dalam pengerjaan poster. Tibalah guru ke kelompok DA, dimana teman sekelompoknya sibuk mengerjakan poster agar cepat selesai akan tetapi DA malah sibuk bermain menggunting kardus. Kemudian melihat kondisi tersebut akhirnya guru menasehati DA agar lebih serius dalam belajarnya, agar tidak terjadi seperti dahulu nilainya tidak jelek dan mendapat peringkat terakhir di dalam kelas. Lalu ketika guru menanyakan kepada DA ketika ia besar nanti mau menjadi apa kalau malas-malasan dan perilakunya kurang baik dimasa depan. DA pun menjawab dengan lantang dalam bahasa jawa yaitu ingin menjadi dai uwong edan yang artinya dalam bahasa indonesua ialah jadi orang gila.

Peneliti melakukan pengamatan pada 20 April 2019 saat itu perilaku agresif secara verbal dari DA terlihat lagi yaitu mengucapkan kalimat ataupun kata-kata hinaan terhadap temannya. Contoh dari DA terhadap perilaku agresif secara verbal ialah ketika saat pembelajaran di dalam kelas bersama guru sedang melakukan kegiatan mencocokan tugas. Saat itu ada teman kelasnya bernama NN, dimana NN salah satu peserta didik yang diminta oleh ibu guru untuk membacakan soal dan menjawab hasil tugasnya akan tetapi NN salah menjawab soal sehingga membuat DA menghina NN seperti bagong dengan bertutur kata kepada NN yaitu dasar bagong salah terus.

Peneliti melakukan pengamatan pada 30 April 2019 saat itu perilaku agresif secara verbal dari DA terlihat lagi yaitu berupa kalimat umpatan. Ketika pagi hari saat pembelajaran di kelas gurupun masuk seperti biasanya, kemudian meminta semua peserta didik untuk mengumpulkan tugas yang diberikan yang minggu lalu oleh guru tersebut, akan tetapi DA tidak membuat tugas yang diberikan oleh gurunya tersebut. Gurupun mengingatkan kembali kepada semua peserta didik bahwa sudah adanya perjanjian dari minggu lalu bahwa kalau ada peserta didik tidak 
membuat tugas maka ia akan dikenakan sanksi berupa mengerjakan tugas tersebut sebanyak 20 kali. Sehingga DA mendapatkan sanksi tersebut untuk mengerjakan tugas sebanyak 20 kali akan tetapi DA menumpat dengan betutur kata dalam bahasa jawa yaitu asu kalau diartikan dalam bahasa indonesia ialah artinya anjing disertai memukul meja yang ada dikelas di dekatnya. Guru mendengar suara dari pukulan dari meja oleh DA di kelas tersebut tapi tidak mendengar kalimat umpatan yang diucapkan oleh DA. Kemudian ada teman sekelasnya DA bernama E, dimana E ini ialah teman sebangkunya DA. E ini mendengar kalimat umpatan yang terucap dari mulutnya DA sehingga $\mathrm{E}$ berniat mengadu kepada guru yang bersangkutan tersebut akan tetapi oleh DA langsung mengusir dan berteriak dengan keras terhadap E dari tempat duduknya tersebut.

Pembelajaran matematika dilaksanakan ketika istirahat selesai sekitar pukul 10.00 WIB. Dimana guru memberikan dan menerangkan materi baru saat pembelajaran matematika berlangsung. Setelah guru selesai menerangkan materi baru tersebut, peserta didik diminta untuk mengerjakan tugas yang diberikan guru. Kemudian, banyak peserta didik yang bertanya mengenai tugas yang diberikan oleh guru dikarenakan materi baru. Lalu, salah satu peserta didik yang bertanya tugas tersebut ialah DA akan tetapi ketika DA memanggil guru dengan maksud untuk dijelaskan kembali cara untuk menyelesaikan tugas yang diberikan oleh guru tersebut, gurunya tidak mendengar kalau dipanggil DA dikarenakan banyak peserta didik yang bertanya bersamaan sehingga membuat DA marah dan emosi dilampiaskan dengan melemparkan pulpen ke lantai di kelas tersebut dan sambil mengumpat dengan berkata bajingan serta serpihan pecahan dari pulpen tersebut dilemparkan ke muka temannya bernama F.

Disimpulkan bahwa berdasarkan hasil observasi dan wawancara yang telah dilakukan oleh peneliti ialah perilaku agresif secara verbal sering dilakukan oleh DA contohnya yaitu kata-kata kotor dan kasar, umpatan, serta hinaan. DA ketika melakukan perilaku agresifnya tersebut saat jengkel, emosi, marah, reflex, dan sengaja mengucapkannya. DA melakukan perilaku agresif secara verbal dikarenakan kebiasaannya, perilaku ini timbul ketika ia merasakan kesakitan secara reflex mengucapkan umpatan ataupun ketika ia sedang marah ataupun emosi.

3) Kemarahan

Perasaan benci tidak mencapai tujuan yang diharapkan terhadap orang lain maupun kegiatan. Berdasarkan hasil pengamatan yang dilakukan oleh peneliti pada 19 April 2019 terhadap DA terlihat perasaan benci terhadap orang lain ketika pergantian jam pelajaran di kelas berlangsung. Teman kelasnya bernama LK, dimana LK dipanggil oleh DA dan menyuruhnya ketempat meja belajar DA di kelas akan tetapi LK menolak. Sehingga membuat DA berteriak lalu dia mengatakan dalam bahasa jawa "cepet rene" yang artinya dalam bahasa Indonesia ialah cepat kesini dengan nada yang tinggi serta membentak seperti orang marah. Akan tetapi LK tetap menolak panggilan dari DA kemudian DA dengan wajah marah lalu dia mengatakan dalam 
bahasa jawa "titenono neng dalan mengko tak cegat koe" yang artinya dalam bahasa Indonesia ialah nanti lihat saja pas dijalan aku cegat atau hadang kamu.

Berdasarkan hasil pengamatan yang dilakukan oleh peneliti pada 30 April 2019 terhadap DA terlihat lagi perasaan benci terhadap orang lain ketika DA belum mencapai tujuan yang ia inginkan saat mengajukan pertanyaan terhadap guru belum diberi respon baik saat jam pelajaran dikelas sehingga membuat DA marah. Guru saat pelajaran masih menjelaskan materi kemudian ada banyak siswa yang bertanya sehingga guru menjelaskan jawaban secara acak satu persatu pertanyaan dari siswa saat itu kelas ramai akan tetapi DA tiba-tiba ingin bertanya terhadap guru yang bersangkutan saat jam pelajaran berlangsung dikelas, akan tetapi guru menjawab kepada DA untuk bersabar dan bergiliran karena masih menjawab pertanyaan dari temannya yang lain akan tetapi DA menolak serta menyahut dengan mengatakan dalam bahasa jawa "wegah, aku sikik bu" yang artinya dalam bahasa Indonesia ialah tidak mau bu, aku duluan dengan diiringin teriakan nada tinggi serta mengebrak meja belajar di dalam kelas.

Berdasarkan hasil pengamatan dan wawancara yang dilakukan oleh peneliti, sehingga dapat disimpulkan bahwa DA memang menunjukkan tingkah laku agresif berupa kemarahan. Perilaku agresif berupa kemarahan ialah diri sendiri adanya perasaan benci berasal dari tidak tercapainya tujuan yang diinginkan. Mengebrak meja belajar, berteriak ataupun melemparkan sesuatu kepada orang lain, ancaman dan sebagainya ialah salah satu contoh bentuk perilaku agresif dari kemarahan. Masalah kecil bisa menimbulkan kemarahan sehingga membuat emosi menjadi tidak stabil seperti biasanya.

4) Permusuhan

Agresi tidak terlihat salah satu bentuk agresinya yaitu permusuhan terdiri dari kebencian dan kecurigaan. DA dalam penelitian ini bentuk agresi dari permusuhan tidak terlihat mengenai kebencian maupun kekhawatiran serta ketidakpercayaan kepada orang lain. DA mempunyai sifat cuek serta acuh tak acuh apabila teman di kelas lebih unggul dan cerdas dan sebagainya. Dalam penelitian ini telah dijabarkan mengenai tingkah laku agresi fisik, verbal serta kemarahan dari DA dimana ia memiliki emosi dan hati yang sangat sensitive sehingga dengan mudah terusulut emosi walaupun hal sepele maka akan telihat secara asli tingkah laku agresifnya.

\section{b. Dampak Yang Ditimbulkan Dari Perilaku Agresif Anak Di Sekolah Untuk Dirinya Sendiri dan Teman-Teman Sekitarnya}

1) Dampak Perilaku Agresif Anak Untuk Dirinya Sendiri

(a) Dijauhi Oleh Teman-Temannya

Dijauhi oleh teman-temannya ialah dampak dari perilaku agresif dari DA. Berdasarkan hasil pengamatan yang dilakukan oleh peneliti pada 18 April 2019 yaitu saat guru yang mengampu pembelajaran prakarya materi dengan membuat poster di dalam kelas membagi kelompok belajar secara acak. Kemudian, DA mendapatkan kelompok 
bersama teman perempuan di dalam kelas akan tetapi mereka pada protes dan tidak ingin sekelompok dengan DA. Salah satu ada teman dari DA bernama R berbicara mengenai perilaku dari DA bahwa kalau dalam mengerjakan tugas kelompok biasanya DA sibuk bermain sendiri, tidak mau membantu mengerjakan tugas kelompok, serta memukul meja belajar di dalam kelas. Lalu, semua teman perempuan yang sekelompok dengan DA bernegoisasi dengan guru yang mengampu saat pembelajaran prakarya untuk dapat DA dimasukkan ke kelompok lain. Setelah itu, guru pun bernegoisasi dengan teman DA berjenis kelamin laki-laki agar dapat menerima DA di kelompok mereka, akan tetapi mereka menolak kalau DA di kelompok belajarnya juga. Akhirnya, DA pun tetap sekelompok dengan kelompok awalnya.

Berdasarkan hasil pengamatan yang dilakukan oleh peneliti pada 30 April 2019 yaitu guru saat jam pembelajaran di kelas memeriksa pekerjaan rumah dari peserta didiknya. Kemudian saat itu guru membagi kelompok duduk bagi yang mengerjakan pekerjaan rumah serta bagi yang tidak mengerjakan pekerjaan rumah. Disini DA tidak mengerjakan pekerjaan rumah sehingga DA duduk dengan temannya bernama $\mathrm{C}$ yang sama-sama tidka mengerjakan PR. Akan tetapi, C mengadu kepada guru serta menolak untuk duduk berdua dengan DA dikarenakan DA mecoret buku milik $\mathrm{C}$ sehingga DA bereaksi ketika C mengadu kepada guru mengenai kejadian kemarin hanya tertawa saja. Disimpulkan bahwa banyak teman-temannya menjauhi perilaku agresif dari DA dikarenakan tidak nyaman serta takut akan perbuatannya tersebut.

Disimpulkan bahwa berdasarkan observasi dan wawancara yang telah dilakukan oleh peneliti ialah teman-teman di dalam kelas banyak menjauhi serta tidak nyaman terhadap perilaku agresif dari DA. Teman DA di kelas tidak mau sebangku atau duduk berpasangan dengannya dikarenakan sering menyakitin. DA apabila ada kerja kelompok saat pembelajaran di kelas dan membentuk kelompok banyak teman-teman DA tidak mau sekelompok dengannya dikarena DA tidak mau bekerja sama dan mengerjakan tugas kelompok. Selain itu, perilaku agresif dari DA yaitu mencoret buku milik temannya, melempar sepatu dari temannya, dan menyembunyikan barang dari temannya. DA ketika jam istirahat sering bermain dengan temannya bernama FR, M maupun dengan kakak kelas V dimana mereka memiliki tingkah laku kejailan yang setara serta dapat dikendalikan antar sesama.

(b) Di Cap Sebagai Anak Yang Membangkang, Nakal, Dan Tidak Sopan

DA mempunyai perilaku agresifnya yaitu membangkang, dimana perilaku membangkangnya tidak dapat dikendalikan semenjak naik di kelas III SD. Peneliti saat melakukan pengamatan melihat perilaku agresif membangkang dari DA tersebut. 
Saat peneliti melakukan pengamatan pada tanggal 18 April 2019 yaitu ketika itu guru meminta tolong kepada DA agar dapat mengambilkan figura foto presiden di dinding kelas akan tetapi DA menolak dengan berkata dalam bahasa jawa yaitu wegah jikuk dewek yang artinya dalam bahasa Indonesia ialah tidak mau ambil sendiri. Saat pembelajaran di dalam kelas ketika pengerjaan kelompok dalam membuat poster, guru menegur DA agar tidak memotong sembarangan kardus yang digunakan dalam pembuatan poster dan jangan ribut sendiri di dalam kelas saat pembelajaran, guru pun berkata kepada DA jangan menghabiskan bahan dalam pembuatan poster, kalau habis kardusnya silahkan cari sendiri. Akan tetapi DA menyahut perkataan dari gurunya tersebut dalam bahasa jawa yaitu halah golek kardus dewe yo iso yang artinya dalam bahasa Indonesia ialah cari kardusnya sendiri juga bisa. Kemudian DA ketika mengerjakan poster dengan bernyanyi suara lantang sehingga menggangu teman-temannya serta guru yang sedang mengampu pembelajaran dikelas tersebut, guru pun menegur kepada DA agar tidak bernyanyi dengan suara yang keras serta segera selesaikan tugasnya tersebut. Akan tetapi DA menjawab perkataan dari gurunya tersebut dalam bahasa jawa yaitu yoben kelas limo yo sok ganggu yang artinya dalam bahasa Indonesia ialah biarin saja kelas lima juga sering ganggu kita kok.

Disimpulkan bahwa berdasarkan observasi dan wawancara yang telah dilakukan oleh peneliti ialah DA dicap memiliki perilaku yang kurang sopan serta membangkang terhadap guru. Apabila guru sedang memberitahu kepada DA, pasti DA selalu membantah, membangkang serta selalu menjawab dengan perkataan tidak sopan dari guru tersebut. Berdasarkan wawancara dengan teman-temannya di kelas mereka menyatakan bahwa DA sering berkata dengan tidak sopan baik kepada teman ataupun guru selain itu DA di cap sebagai anak yang paling nakal di dalam kelas oleh teman-temannya.

(c) Mempunyai Prestasi Rendah

Mempunyai prestasi yang rendah ialah salah satu dampak dari perilaku agresif DA pada pendidikannya di sekolah. DA mudah putus asa ketika tidak bisa mengerjakan tugas ataupun pekerjaan rumah yang diberikan oleh guru dikarenakan emosi mudah naik turun dari DA. Saat peneliti melakukan pengamatan pada tanggal 30 April 2019 yaitu ketika guru menjelaskan pembelajaran matematika dikelas, lalu guru memberikan tugas sebanyak 7 soal cerita untuk dikerjakan, serta bagi siswa/i yang telah selesai mengerjakan tugas boleh pulang ke rumahnya masing-masing akan tetapi DA menjadi siswa yang terakhir pulang dikarenkan baru selesai mengerjakan tugas dari gurunya tersebut. DA saat guru menerangkan pembelajaran matematika dikelas ia sibuk bermain sendiri serta mengganggu teman lainnya, sehingga ketika ia mengerjakan soal cerita yang diberikan guru mengalami kesulitan kemudian ia berusaha untuk bertanya kepada guru yang bersangkutan akan tetapi guru tersebut tidak dapat mendengar kalau DA bertanya dikarenakan banyak siswa/i yang 
bertanya juga sehingga membuat DA pun marah. DA pun melampiaskan kemarahannya dengan berkata mengumpat bajingan serta dengan melemparkan pena ke lantai. Kemudian pecahan dari pena yang dibantingnya tadi dilemparkan ke muka kepada temannya bernama F. DA keluar dari tempat duduknya lalu mengganggu teman yang bernama $\mathrm{W}$ dengan cara mengambil buku dari W kemudian buku W dilemparkan ke muka F oleh DA. Selain itu DA jalan-jalan di dalam kelas padahal guru masih menerangkan pembelajaran. DA pun merusak jendela kelas dengan menggunakan pena yang dia miliki, kemudian ada teman kelasnya bernama MS dimana perilaku agresif dari DA ia melemparkan sapu lidi di kepala FM. Contoh lainnya yaitu DA merobek buku temannya bernama F serta mengoyanggoyangkan meja belajar temannya bernama MS ketika MS mengerjakan soal yang diberikan tugas oleh guru.

Disimpulkan bahwa berdasarkan observasi dan wawancara yang telah dilakukan oleh peneliti bahwa akibat dari perilaku agresif DA ialah memiliki prestasi yang rendah. DA apabila tidak bisa mengerjakan tugas baik pekerjaan rumahe ataupun soal yang diberikan oleh gurunya maka DA akan mudah emosi sehingga tidak akan mengerjakan tugas tersebut lalu akan marah dikarenakan putus asa serta tidak adanya semangat lagi untuk mengerjakan tugasnya itu sehingga biasanya DA akan mengganggu teman lainnya yang ada di kelas ketika mereka mengerjakan tugas hal ini dikarenakan perilaku anak agresif mudah emosi atau tidak bisa mengontrol emosinya tersebut.

2) Dampak Perilaku Agresif Anak Untuk Teman Disekitarnya

(a) Merugikan Temannya Yang Menjadi Korban

Bagi teman-teman disekitar DA dampak perilaku agresifnya mengakibatkan banyak kerugian. Telah dipaparkan bahwa teman disekitar DA merasakan sakit sampai menangis ini merupakan dampak dari kerugian perilaku agresif DA secara fisik. Saat peneliti melakukan pengamatan pada tanggal 30 April 2019 yaitu DA ketika pembelajaran matematika di dalam kelas dia tidak mengerjakan soal matematika yang telah diberikan oleh gurunya akan tetapi DA mengganggu temannya. Teman kelasnya bernama F lalu DA tiba-tiba duduk bersebelahan dengan $\mathrm{F}$ setelah itu $\mathrm{F}$ ada yang tidak paham dengan soal matematika sehingga F maju kedepan ke meja guru, akan tetapi $\mathrm{F}$ setelah selesai bertanya dengan guru dan akan kembali ke tempat duduk di dalam kelas tiba-tiba DA menyobek buku $\mathrm{F}$ tanpa alasan, sehingga membuat $\mathrm{F}$ menangis melihat yang dilakukan DA terhadap bukunya tersebut ini merupakan kerugian perilaku agresif DA secara materi dan psikis.

Disimpulkan bahwa berdasarkan obervasi, wawancara, serta dokumentasi yang telah dilakukan peneliti bahwa perilaku agresif DA banyak merugikan secara fisik sampai materi dari teman disekitarnya. DA sering menghancurkan barang dari temannya contoh buku, pulpen dan suka menyembunyikan barang dan tidak dikembalikan kepada pemiliknya 
selain itu DA sering meminta duit kepada temannya baik laki-laki maupun perempuan padahal uang jajan DA lebih dari cukup.

(b) Membuat Siswi Perempuan Ketakutan

Peneliti melakukan pengamatan pada 30 April 2019, saat itu di dalam kelas melakukan duduk secara acak yaitu sepasang lali-laki dengan wanita yang dilakukan oleh wali kelas DA kebetulan ada teman wanita yang dipasangkan dengan DA di dalam kelas yaitu C. Akan tetapi, C tidak mau di pasangkan dengan DA dikarenakan DA sering mencoret-coret bukunya C. Walaupun wali kelasnya mengganti dengan wanita lain semua menolak untuk dipasangkan sebangku dengan DA di dalam kelas. Sehingga wali kelasnya bertanya kepada semua wanita di dalam kelas, adakah yang mau duduk dengan DA, untungnya ada satu-satunya wanita yang mau dipasangkan dengan DA yaitu $P$. Disimpulkan bahwa DA membuat wanita didalam kelas takut berada didekatnya pada perilaku agresif dari DA.

Ada teman DA yang bernama $\mathrm{P}$ ialah wanita satu-satunya yang berani membalas terhadap perilaku agresif dari DA. P ketika duduk berpasangan di dalam kelas mendapatkan perlakukan dari DA secara tiba-tiba berupa teriakan dengan nada yang kencang serta tinggi di telinga $\mathrm{P}$, sehingga membuat $\mathrm{P}$ terkejut dan membuat telinganya berdengung sakit. Tidak lama kemudian, DA melakukan kejailan berupa meniupkan pruit dengan kencang ditelinga P sehingga dengan reflex P mendorong DA hingga terjatuh dari bangku di dalam kelas. Akan tetapi, kepala sekolahpun datang ke kelas IV dikarenakan mendengar ada suara pluit yang sangat kencang, lalu kepala sekolah bertanya siapa yang meniup pluit tersebut kemudian kepala sekolah menegur DA agar tidak melakukan perbuatannya serta menyita pluit tersebut dari DA.

Berdasarkan hasil pengamatan di atas yang dilakukan oleh peneliti yang diperkuat oleh pernyataan dari guru atau wali kelas DA bernama Ibu FN bahwa DA suka sering menjaili dan membuat menangis wanita yang ada di dalam kelas, sehingga sebelum menjadi korban perilaku agresif dari DA murid wanita di kelas lebih baik menghindar akan tetapi ada satu wanita yang di dalam kelas yang berani membalas perilaku agresif ataupun kejailan dari DA yaitu P contohnya apabila DA tangannya maju ke wajah P, maka P akan membalas dengan cara yang sama.

Disimpulkan bahwa berdasarkan observasi, wawancara, serta dokumentasi yang telah dilakukan peneliti bahwa teman yang berjenis kelamin wanita pada ketakutan terhadap perilaku agresif secara fisik maupun kejailan dari DA sehingga banyak teman cewek dari DA lebih baik menghindar dari pada menjadi korban perilaku agresifnya dikarenakan takut akan kejadian terulang kembali terkhusus pada korbannya. Ada teman 
Dita Ratna Sari, Mizaniya, Ahmad Noviansyah : Perilaku Agresif Anak Disebabkan Orang Tua Merantau

kelasnya bernama $\mathrm{P}$ yang berjenis kelamin wanita, dia merupakan satu-satunya yang berani membalas perilaku agresif dan kejailan dari DA di dalam kelas.

\section{KESIMPULAN}

Kesimpulan yang dapat ditarik dalam penelitian ini tentang tingkah laku agresif anak yang disebabkan oleh orang tua merantau yaitu: Pertama, DA memperlihatkan bentuk-bentuk tingkah laku agresif anak yang disebabkan oleh orang tua merantau di pendidikan formal yakni sekolah dasar antara lain mementung (menggebuk), menjorokkan (memerosokkan), mencengkam, menerjang, menghalangi (menjatuhkan), melantingkan gunting maupun pena, mengejek (meledek), mengupat, mengancam, berkata kasar dan kotor, memukul meja, menjerit (memekik), sedangkan pada penelitian ini untuk kategori permusuhan tidak tampak. Kedua, DA akibat yang timbul dari tingkah laku agresif terhadap pribadi sendiri yaitu dihindari teman-teman sekitarnya, dinamakan atau dianggap seperti anak memberontak (melawan), usil (bandel) serta tidak sopan, dan memiliki prestasi kecil (kurang) sedangkan DA akibat dari tingkah laku agresif terhadap kawan sejawat dilingkungan sekitarnya yaitu membebani (mudarat) bagi korban yakni kawan sejawat serta membikin peserta didik wanita menjadi takut terhadapnya.

\section{DAFTAR PUSTAKA}

Adhiputra, Anak Agung Ngurah. (2013). Bimbingan dan Konseling Aplikasi di Sekolah Dasar dan Taman Kanak-Kanak. Yogyakarta: Graha Ilmu.

Anantasari. (2006). Menyikapi Perilaku Agresif Anak. Yogyakarta: Kanisius.

Chairunnissa, Connie. (2007). Metode Penelitian Ilmiah Aplikasi dalam Pendidikan dan Sosial. Jakarta: Mitra Wacana Media.

Djanaid, Djanalis., dan Maharjo. (2011). Manajemen dan Leadership dalam Budaya Minangkabau. Malang: Universitas Brawijaya Press.

Fathi, Bunda. (2011). Mendidik Anak dengan Al-Qur'an Sejak Janin. Jakarta: Grasindo.

Fitrah, Muh., dan Luthfiyah. (2017). Metodologi Penelitian (Penelitia Kualitatif, Tindakan Kelas dan Studi Kasus). Jawa Barat: CV Jejak.

Gunarsa, Yulia Singgih D. (2008). Psikologi Perkembangan Anak dan Remaja. Jakarta: PT BPK Gunung Mulia.

Hidayat, Komaruddin., dan Khoiruddin Bashori. (2016). Psikologi Sosial: Aku Kami dan Kita. Jakarta: Erlangga.

Indonesia, CNN. (2018). Diunduh dari laman web https://www.cnnindonesia.com/gayahidup/20181222032125-284-355682/pilihan-ibu-berkarier-atau-mengurus-anak-tak-pernah-salah Pada tanggal 02 Februari 2019 Pukul 10.10 WIB.

PAI, Tim Dosen. (2016). Bunga Rampai Penelitian dalam Pendidikan Islam. Yogyakarta: CV Budi Utama. 
Dita Ratna Sari, Mizaniya, Ahmad Noviansyah : Perilaku Agresif Anak Disebabkan Orang Tua Merantau

Prastowo, Andi. (2011). Metode Penelitian Kualitatif dalam Perspektif Rancangan Penelitian. Yogyakarta: Ar-Ruzz Media.

Statistik, Berita Resmi. (2018). Keadaan Ketenagakerjaan Indonesia Februari 2018. Diunduh dari laman web http://www.turc.or.id/wp-content/uploads/2018/06/BPS_Berita-Resmi-Statistik_KeadaanKetenagakerjaan-Indonesia-Februari-2018.pdf Pada tanggal 04 Desember 2018 pukul 14.45 WIB.

Sugiyono. (2016). Metode Penelitian Kuantitatif, Kualitatif, dan R\&D. Bandung: Alfabeta.

Suprihatin, Titin. (2011). Agresivitas Anak (Suatu Studi Kasus). Jurnal Proyeksi, 6(1), 53-61.

Syamaun, Nurmasyithah. (2012). Dampak Pola Asuh Orang Tua dan Guru Terhadap Kecenderungan Perilaku Agresif Siswa. Yogyakarta: Ar-Ruzz Media.

Yusuf, Muri. (2017). Metode Penelitian Kuantitatif, Kualitatif, \& Penelitian Gabungan. Jakarta: Kencana.

Wahyuning, Wiwit., Jash dan Metta Rachmadiana. (2003). Mengkomunikasikan Moral Kepada Anak. Jakarta: PT Elex Media Komputido. 